\title{
ANALISIS DAN PERANCANGAN SISTEM INFORMASI SEBAGAI PENUNJANG KEPUTUSAN PADA UKM PD GERAK TANI JAKARTA
}

\author{
Dewan Pelawi \\ Information Systems Department, School of Information Systems, Binus University \\ Jl. K.H. Syahdan No. 9, Palmerah, Jakarta Barat 11480 \\ dewanpelawi@yahoo.com; dewanpelawi2318@binus.ac.id
}

\begin{abstract}
To maintain a trading business in the strict competition a management supported by appropriate business strategy is required. Utilization of an information system that supports decision-making is needed to improve performance as well as support for all lines of business. Therefore, a research is conducted that specifically aims at the development of decision support systems for small and medium enterprises (SMEs). The basic method for building the system is the Herbert Simon's four-stage decision-making approach: intelligence, design, choice and implementation. Following is the building of data management subsystem, management subsystem model and user interface subsystem. The development of this system results in a decision support system that can improve the performance of all business lines complemented with support information for decision making.
\end{abstract}

Keywords: information system, decision support system, Herbert Simon, data management subsystem, model management subsystem, user interface subsystems

\begin{abstract}
ABSTRAK
Untuk mempertahankan suatu usaha dagang dengan tingkat persaingan yang ketat dibutuhkan pengelolaan yang didukung oleh strategi bisnis yang tepat. Pemanfaatan suatu sistem informasi yang menunjang pengambilan keputusan dibutuhkan untuk meningkatkan kinerja dan dukungan terhadap semua lini dalam usaha. Untuk itu dilakukan penelitian yang bertujuan khusus dalam pengembangan sistem penunjang keputusan untuk usaha kecil menengah ( UKM). Metode dasar untuk membangun sistem tersebut adalah empat tahap pendekatan pengambilan keputusan menurut Herbert Simon meliputi tahap intelligence, design, choice dan implementation. Kemudian dilanjutkan dengan membangun data management subsystem, model management subsystem dan user interface subsystem. Pengembangan sistem ini menghasilkan sebuah sistem penunjang keputusan yang dapat meningkatkan kinerja semua lini dengan dukungan informasi untuk pengambilan keputusan.
\end{abstract}

Kata kunci: sistem informasi, sistem penunjang keputusan, Herbert Simon, data management subsystem, model management subsystem, user interface subsystems 


\section{PENDAHULUAN}

Perkembangan teknologi informasi mengubah lingkungan bisnis dari tradisional menjadi modern. Tuntutan persaingan ekonomi global mengharuskan usaha untuk memiliki sistem informasi. Dengan adanya sistem informasi aliran informasi menjadi sangat banyak dan menjadi masalah jika kurang terorganisasi dengan baik. Permasalahan yang dihadapi perusahaan untuk dipecahkan harus didukung oleh ketersediaan informasi yang sesuai, tepat waktu, lengkap dan akurat. Perencanaan dan strategi bisnis yang baik disusun berdasarkan informasi yang dimiliki baik internal maupun eksternal. Persaingan bisnis memberikan tekanan kepada organisasi baik pribadi maupun perusahaan umum untuk merespon dengan cepat perubahan yang terjadi dan dituntut menjadi lebih inovatif untuk melaksanakan operasional usahanya. Hal ini menuntut usaha untuk menerapkan stategi yang cepat dan taktis sehingga membuat keputusan operasional semakin rumit mengingat untuk menghasilkan keputusan dibutuhkan pertimbangan data, informasi dan pengetahuan yang relevan.

PD. Gerak Tani adalah sebuah usaha kecil menengah (UKM) yang bergerak dalam bidang produksi dan penjualan bumbu dapur. PD. Gerak Tani didirikan pada tanggal 2 Mei 1977, dan dikembangkan oleh Drs. N.J. Sembiring. Keunggulan produk Gerak Tani adalah tanpa penggunaan MSG dan pengawetan dilakukan bekerja sama dengan PATIR BATAN menggunakan teknologi irradiasi dengan sinar gamma. Ketersediaan bahan baku, produksi yang sesuai dan benar, pelayanan pelanggan yang baik dan memuaskan, kordinasi semua bagian yang terarah adalah kunci keberhasilan dari usaha ini. Pengeluaran dan pemasukan barang ke gudang, rencana jumlah produksi, apa yang diproduksi, berapa dan apa bahan mentah yang harus dibeli, berapa dan apa barang jadi setelah produksi adalah sesuatu yang sulit langsung diketahui jika belum ada organisasi data yang baik. Kesulitan inilah yang sering dihadapi oleh usaha dagang Gerak Tani dalam menjalankan bisnisnya. Pihak pemilik menyadari bahwa kehadiran TI sebagai suatu strategi yang dapat mendukung kegiatan bisnis. Oleh karena itu diharapkan adanya suatu aplikasi sistem penunjang keputusan yang akan membantu dalam menyelesaikan permasalahan tersebut.

Tujuan penelitian ini adalah membantu UKM khususnya usaha dagang Gerak Tani dalam meningkatkan produktifitas pengambilan keputusan manajerial dan meningkatkan kualitas data management untuk perencanaan strategis.

Proses pengambilan keputusan menurut Herbert Simon (dalam Turban, 2007) terdiri dari empat tahap yaitu intelligence, design, choice, implementation (Gambar 1). Pada tahap intelligence kegiatan yang dilakukan adalah: (1) mengawasi/meneliti lingkungan; (2) menganalisis tujuan organisasi; (3) mengumpulkan data; (4) mengidentifikasi masalah; (5) mengkategorikan masalah (programable/non programable); (6) menilai stakeholder dan penanggung jawab masalah. Kemudian kegiatan pada tahap design adalah: (1) mengembangkan tindakan alternatif; (2) membuat analisis solusi terbaik; (3) menyusun model; (4) melakukan tes kelayakan; (5) melakukan validasi hasil; (6) menetapkan prinsip-prinsip pemilihan, seperti objektif, model, penilaian terhadap risiko, serta kriteria dan batasan. Selanjutnya, tahap choice adalah bagian paling kritis dalam pengambilan keputusan. Pada tahap ini dilakukan: (1) pemilihan yang berprinsip pada pendekatan solusi, seperti: optimisasi, rasionalisasi, suboptimisasi, model desktiptif; (2) evaluasi dan rekomendasi. Pada tahap terakhir implementation - dilakukan pelaksanaan pada pilihan solusi.

Decision support system (DSS) adalah aplikasi untuk mendukung tugas-tugas manajemen pada umumnya dan membantu pengambilan keputusan pada khususnya. DSS disebut juga sistem pendukung keputusan (SPK) atau bisnis intelijen (BI). 


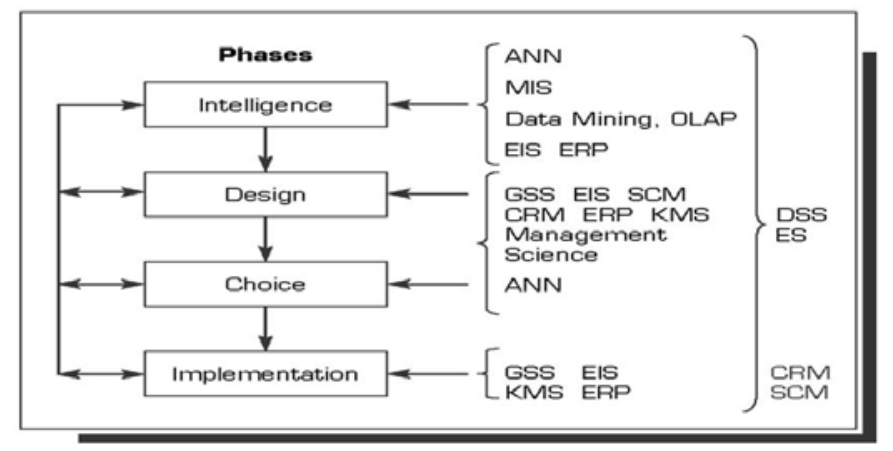

Gambar 1. Dukungan terhadap proses pengambilan Keputusan (Turban, 2007).

Beberapa karakteristik dan kemampuan SPK di antaranya: (1) mendukung pengambilan keputusan terstruktur atau semi terstruktur; (2) mendukung semua tingkatan manajemen (top level sampai line manajemen); (3) mendukung semua individu maupun grup; (4) mendukung pengambilan keputusan yang berurutan maupun saling bergantungan; (5) mendukung semua tahap pengambilan keputusan (intelligence, design, choice, implementation); (6) mendukung semua model proses pengambilan keputusan dan gayanya; (7) dapat disesuaikan dengan situasi; (8) menggunakan sentuhan perasaan yang terdalam; (9) meningkatkan efektifitas pengambilan keputusan; (10) dapat dikontrol oleh pengguna; (11) dapat dikembangkan dan dimodifikasi oleh pengguna sesuai kebutuhan; (12) model dapat dibuat secara umum untuk situasi pengambilan keputusan; (13) menyediakan akses data dalam format, tipe dan cakupan bahkan area geografis; (14) dapat dioperasikan pada perangkat standalone (PC) atau dalam jaringan (distributed).

Adapun komponen SPK (Gambar 2) di antaranya: (1) data management subsystem (DMS); (2) user interface (UI) subsystem; (3) model manajemen subsystem (MMS); (4) knowledge-based management subsystem (KBMS).

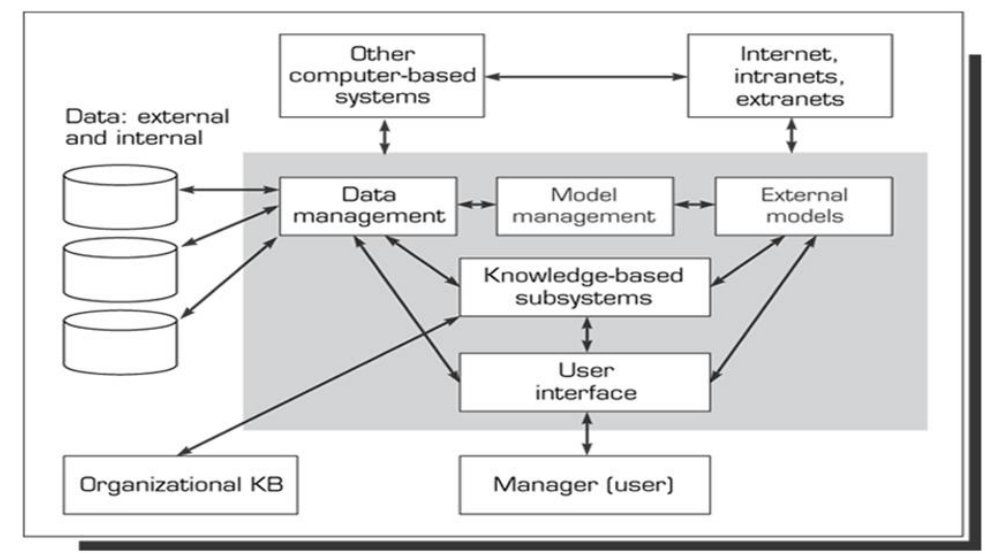

Gambar 2. Model konseptual SPK (Turban, 2007).

\section{METODE}

\section{Analisis Kebutuhan Sistem}

Analisis kebutuhan atau persyaratan sistem digunakan untuk menentukan atau memberikan 
gambaran secara umum sistem seperti apa yang dibutuhkan para stake holder yang dapat membantu atau mendukung pencapaian sasaran organisasi yang meliputi: (1) kebutuhan data dan informasi yang berkaitan operasional perusahaan; (2) kebutuhan proses atau fungsi dari sistem, dalam pengertian apa yang dapat dilakukan oleh sistem untuk para pengguna atau user dalam menjalankan tugas berkaitan dengan pengelolaan informasi data barang masuk, barang keluar dan penjualan; (3) kebutuhan antarmuka atau interface, yang memudahkan para pengguna berinteraksi dengan sistem sesuai dengan tingkat kebutuhan masing-masing pengguna. Untuk itu analisis kebutuhan system dilakukan pada fungsi bisnis gudang dan administrasi. Kebutuhan-kebutuhan yang didapatkan dianalisis secara teknis dengan pendekatan objek dan model sistem, dan menghasilkan sebuah konsep sistem.

\section{Pengidentifikasian Fakta}

Pengidentifikasian fakta dilakukan melalui metode survei dan wawancara.

\section{Perancangan Sistem}

Dari hasil analisis kebutuhan atau persyaratan system dan model sistem, disusunlah spesifikasi teknis untuk mewujudkan setiap bagian atau komponen sistem, diantaranya: (1) spesifikasi basis data, yaitu menentukan apa saja yang dibutuhkan untuk penyimpanan data dan penyiapan informasi yang disebut dengan subdata management; (2) spesifikasi model-model untuk membantu memodelkan masalah untuk pencarian pemecahan permasalahan, yang disebut dengan submodel management; (3) spesifikasi antar muka atau interface untuk memudahkan pengguna berinteraksi dengan sistem dan mendapatkan informasi dijelaskan secara rinci - termasuk media yang digunakan melalui print-out atau tampilan layar serta menu yang mengaturnya - yang disebut dengan subuser interface.

\section{Pengembangan Sistem Pendukung Keputusan}

Berdasarkan spesifikasi dari komponen-komponen sistem pendukung keputusan, kemudian dikembangkan suatu aplikasi sistem pendukung keputusan sesuai dengan teknologi terpilih, meliputi: (1) Pengembangan domain data dengan penciptaan tabel-tabel untuk membentuk basis data yang diusulkan menggunakan model relasional; (2) Pengembangan domain model dengan penciptaan model-model untuk memodelkan permasalahan yang diusulkan menggunakan model-model relevan.

\section{HASIL DAN PEMBAHASAN}

\section{Proses Produksi}

Secara garis besar proses produksi yang dilakukan terdiri dari enam tahap penting, yaitu pemilihan bahan baku, pencucian, balancing, penggilingan, pengemasan, dan irradiasi sebelum dikirim ke penyimpanan. Gerak Tani saat ini melakukan pemasaran 0,5 ton per hari di mana kapasitas produksi mencapai 1 ton perhari dengan jumlah tenaga kerja 25 orang dan jumlah komoditi yang di olah kurang lebih 50 jenis. Adapun permasalahan yang dihadapi oleh Gerak Tani saat ini adalah: (1) pencatatan keuangan perusahaan baik pendapatan, pengeluaran masih dilakukan manual sehingga rugi laba sulit diketahui dengan segera; (2) pengeluaran barang dari gudang dan yang masuk ke gudang yang belum tercatat.

\section{Analisis Kebutuhan Sistem} (Tabel 1):

Dari proses bisnis yang terjadi pada PD. Gerak Tani didapat kebutuhan data sebagai berikut 
Tabel 1

Kebutuhan Data PD. Gerak Tani

\begin{tabular}{lll}
\hline Fungsi Bisnis & Proses Bisnis & Kebutuhan Data \\
\hline Gudang & Penerimaan barang & Penerimaan_barang \\
& Pengeluaran barang & Pengeluaran_barang, \\
\hline Administrasi & Membukukan semua transaksi pendapatan & Pendapatan, Pengeluaran \\
& Membukukan semua transaksi pengeluaran & \\
& Membuat perintah pengeluaran barang dari gudang & \\
& Menerima laporan penerimaan barang dari gudang & \\
& Menerima laporan pengeluaran barang dari gudang & \\
& Melakukan pembayaran & \\
\hline
\end{tabular}

Selain itu, ditemukan pula kebutuhan antarmuka dan fungsi dari sistem sebagai berikut (Tabel 2).

Tabel 2

Kebutuhan Antarmuka dan Fungsi dari Sistem

\begin{tabular}{|c|c|c|c|}
\hline No & $\begin{array}{l}\text { Antar Muka / User } \\
\text { Interface }\end{array}$ & Fungsi dari Sistem & $\begin{array}{l}\text { Fungsi } \\
\text { Bisnis }\end{array}$ \\
\hline 1 & Input Stock ( Barang masuk) & Memasukkan data raw material ke gudang & Gudang \\
\hline 2 & Item Barang & Mengedit data batang & Administrasi \\
\hline 3 & Contact & $\begin{array}{l}\text { Form ini untuk mencatat data Contact Toko, Karwayan, Customer } \\
\text { dan Suplier }\end{array}$ & Administrasi \\
\hline 4 & Barang Keluar & Meminta pengeluaran produk dari gudang & Administrasi \\
\hline 5 & Laporan barang masuk & Laporan barang masuk & Gudang \\
\hline 6 & Laporan Barang keluar & Laporan barang keluar & Gudang \\
\hline 7 & Form Pendapatan & Laporan pendapatan & Administrasi \\
\hline 8 & Form Pengeluaran & Laporan pengeluaran & Administrasi \\
\hline 9 & Laporan rugi laba & Laporan rugi laba & Administrasi \\
\hline 10 & $\begin{array}{l}\text { Laporan } \\
\text { perusahaan }\end{array}$ & Laporan pengeluaran perusahaan & Administrasi \\
\hline
\end{tabular}

\section{Permodelan yang Digunakan}

Tabel 3 berikut menginformasikan model-model yang digunakan untuk setiap fungsi sistem.

Tabel 3

Permodelan untuk Fungsi Sistem

\begin{tabular}{lll}
\hline No & \multicolumn{1}{c}{ Fungsi sistem } & \multicolumn{1}{c}{ Model yang digunakan } \\
\hline 1 & Input Stock ( Barang masuk) & Penambahan raw material terhadap raw material yang ada saat ini \\
2 & Item Barang & Edit item barang tersedia \\
3 & Contact & Mencatat data contact toko, karyawan, customer dan supplier \\
4 & Barang Keluar & Pengurangan produk dari produk yang ada di gudang \\
5 & Laporan barang masuk & Resume barang masuk \\
6 & Laporan Barang keluar & Resume barang keluar \\
7 & Form Pendapatan & Resume pendapatan \\
8 & Form Pengeluaran & Resume pengeluaran \\
9 & Laporan rugi laba & Resume pendapatan dikurang pengeluaran \\
10 & Laporan pengeluaran perusahaan & Resume pengeluaran perusahaan \\
\hline
\end{tabular}

\section{Perancangan}

\section{Stok Barang}

Berikut ini beberapa perancangan antarmuka yang dibuat untuk sistem stok (Gambar 3 - 5). 


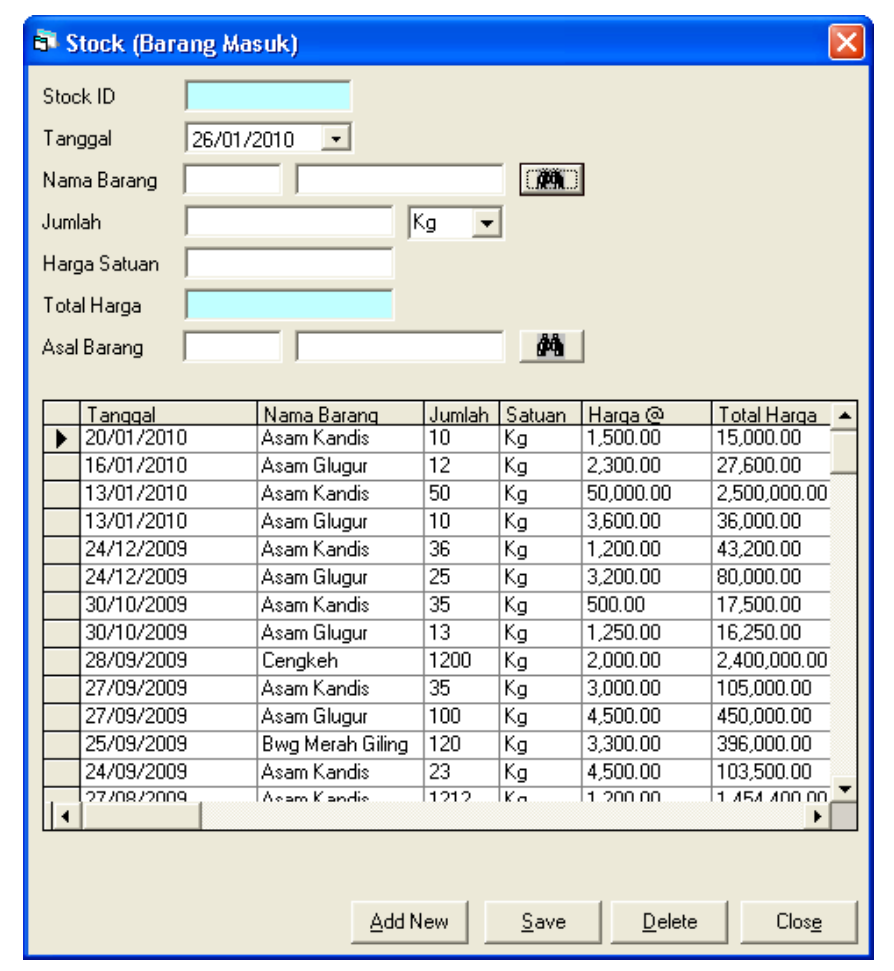

Gambar 3. Antarmuka stok (barang masuk).

Untuk menambah data baru: (1) klik kiri tombol "Add New" untuk menambah data baru; (2) pilih tanggal; (3) isi kode barang jika anda sudah hapal kode barang. Otomatis akan keluar nama barangnya. Jika pengguna belum hapal kode barang dapat menekan tombol teropong pada sebelah kanan textbox Nama Barang sehingga akan muncul form seperti dibawah ini (Gambar 4):

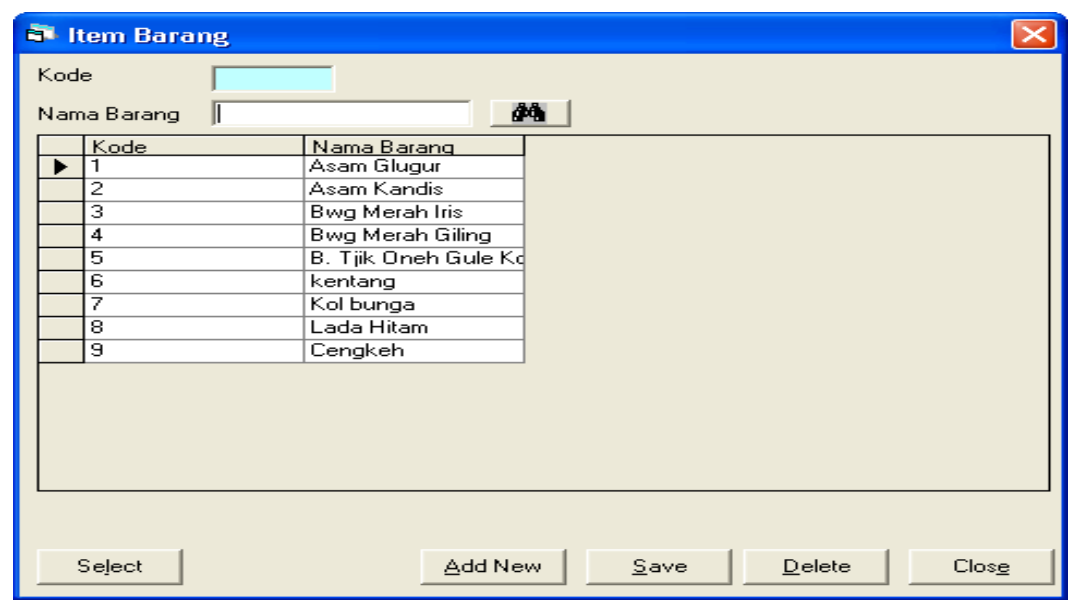

Gambar 4. Antarmuka kode dan nama barang.

Lalu pilih barang yang hendak dipakai. Klik kiri pada tombol "Select” untuk memilih barang tersebut; (4) Isi jumlah barang yang masuk ke gudang; (5) Masukkan harga per satuan; (6) Sistem akan menampilkan total harga; (7) Masukkan kode asal barang jika sudah hapal, atau tekan tombol teropong pada sebelah kanan "Asal Barang” sehingga muncul form seperti dibawah ini (Gambar 5): 


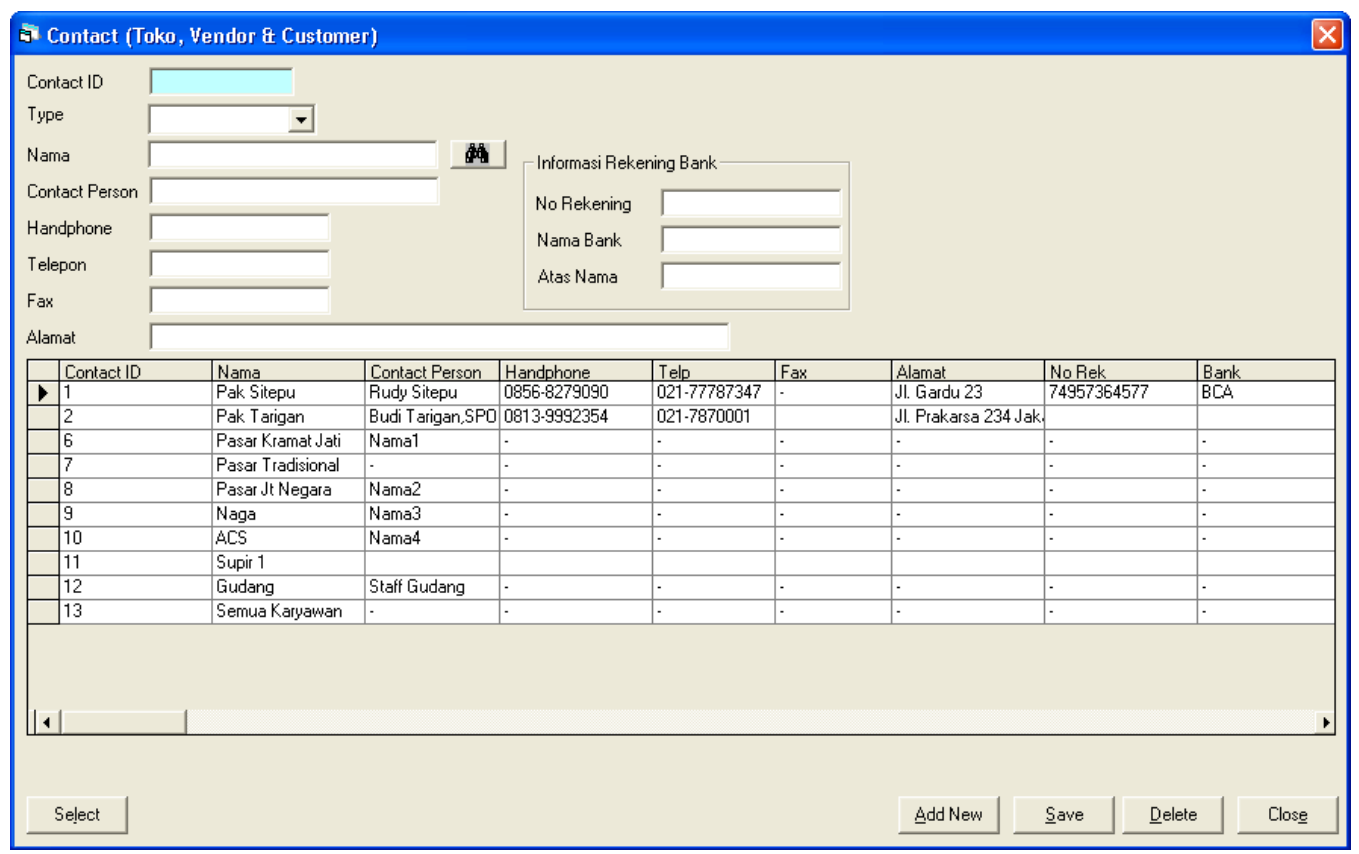

Gambar 5. Antarmuka asal barang.

Untuk mengedit data: (1) Pilih data pada tabel dengan melakukan klik kiri pada baris tabel; (2) Lakukan perubahan yang diinginkan pada text box; (3) Klik kiri tombol "Save” untuk menyimpan.

\section{Sirkulasi Barang}

Berikut ini perancangan antarmuka yang dibuat untuk sistem sirkulasi barang (Gambar 6 -8).

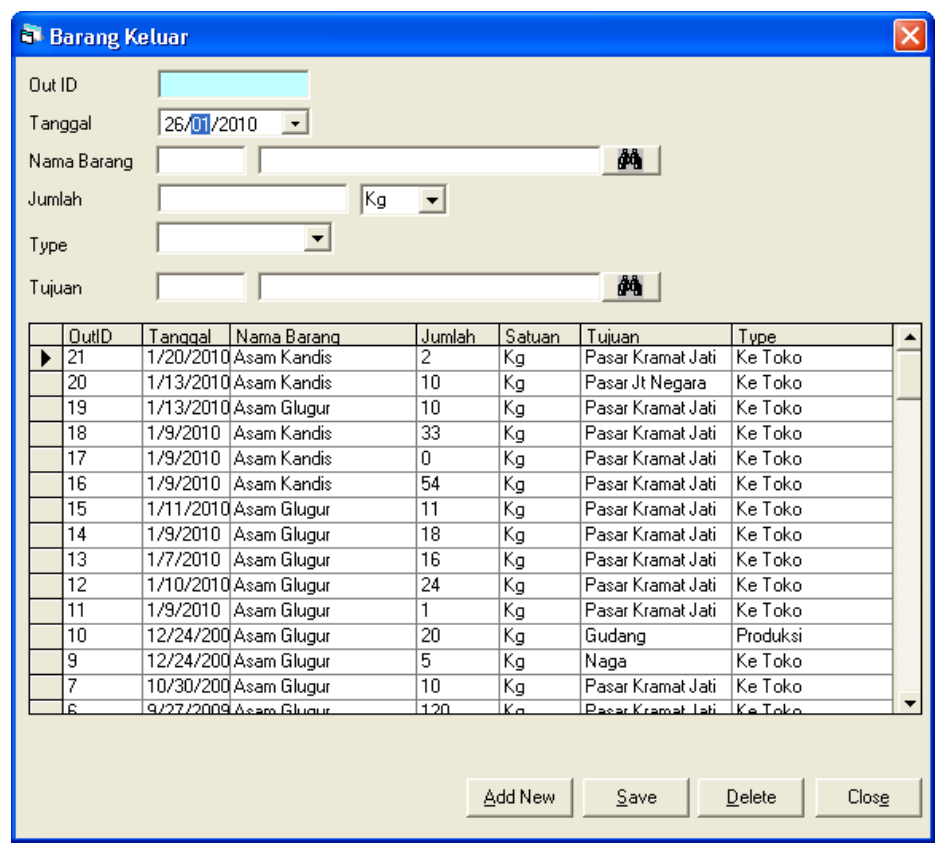

Gambar 6. Antarmuka barang keluar. 
Untuk menambah data baru barang keluar: (1) Klik kiri tombol "Add New" untuk menambah data baru; (2) Pilih tanggal; (3) Isi kode barang jika anda sudah hapal kode barang. Otomatis akan keluar nama barang. Jika anda belum hapal kode barang dapat menekan tombol teropong pada sebelah kanan text box Nama Barang; (4) Isi jumlah dan pilih tipe satuan; (5) Pilih tipe barang keluar; (6) Isi kode tujuan dan tekan "Enter" atau dapat dipilih dari look up form dengan menekan tombol gambar teropong di sebelah kanan text box Tujuan.

Untuk membuat laporan barang masuk: (1) Isi batasan tanggal dari tangal berapa sampai tanggal berapa; (2) Ketik kode barang, tekan "Enter" untuk menampilkan deskripsi kode barang; (3) Tekan tombol "Generate” untuk menampilkan laporan (Gambar 7).

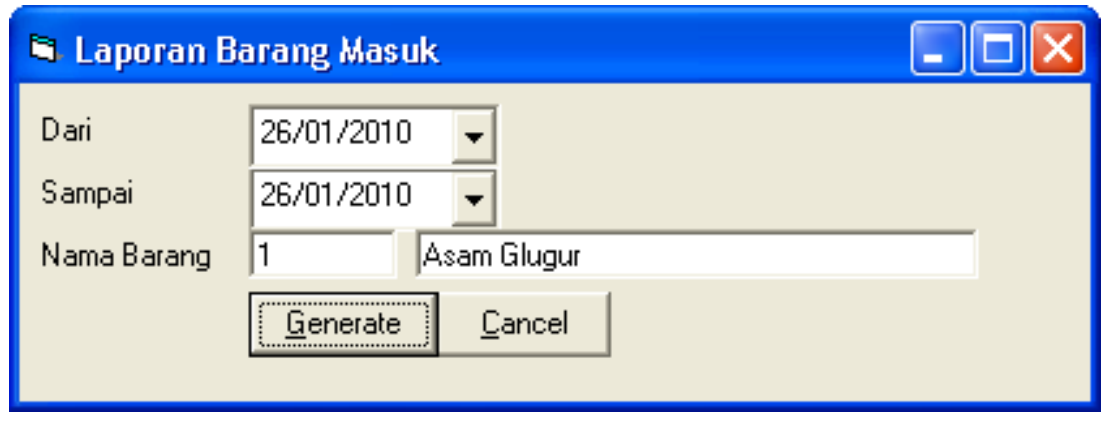

Gambar 7. Antarmuka untuk membuat laporan barang masuk.

Untuk membuat laporan barang keluar: (1) Pilih periode bulan; (2) Isi tujuan dengan kode, tekan "Enter" untuk menampilkan deskripsi kode tujuan; (3) Tekan tombol "Generate” untuk menampilkan laporan (Gamabr 8).

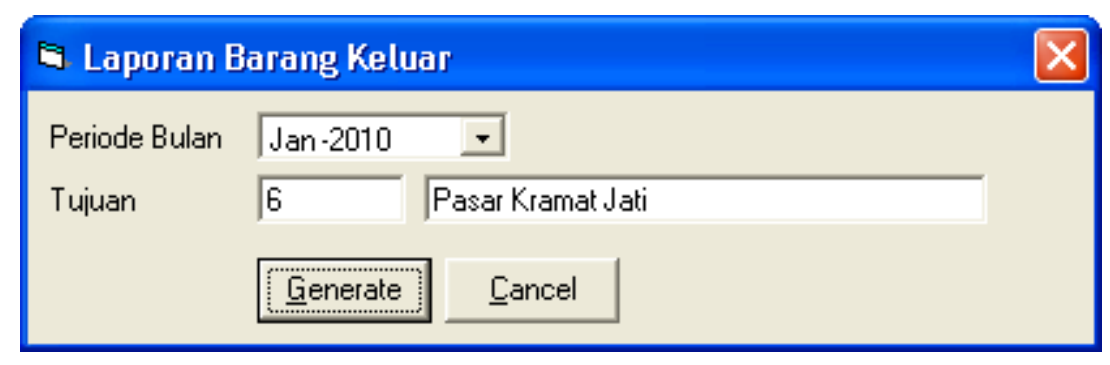

Gambar 8. Antarmuka untuk membuat laporan barang keluar per tujuan barang.

\section{Keuangan}

Untuk mencatat transaksi pendapatan (Gambar 9); (1) Pilih sumber pendapatan; (2) Pilih tanggal transaksi; (3) Isi keterangan; (4) Isi pendapatan Pagi dengan pendapatan pagi. Textbox ini menjadi default untuk diisi jika tidak ada pembagian antara pendapatan pagi dan sore; (5) Isi pendapatan Sore jika ada; (6) Isi pendapatan Tambahan jika ada. Total pendapatan akan dihitung oleh sistem secara otomatis. 


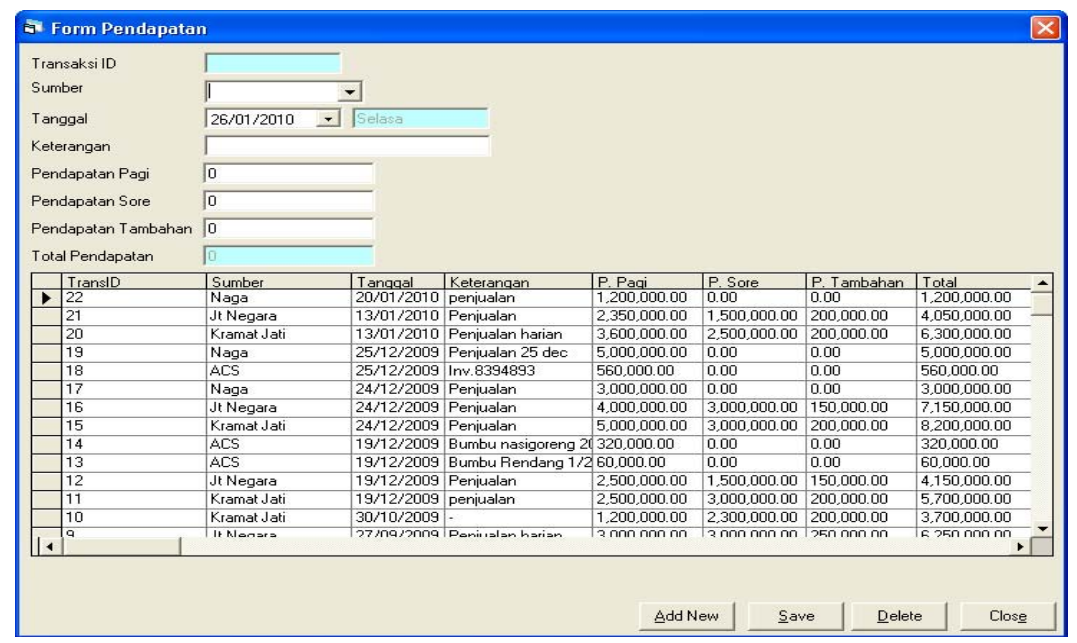

Gambar 9. Antarmuka untuk mencatat transaksi pendapatan.

Untuk mencatat transaksi pengeluaran (Gambar 10): (1) Pilih sumber pengeluaran; (2) Pilih tanggal transaksi. Nama hari akan otomatis ditampilkan; (3) Isi keterangan, untuk bahan baku tertentu dapat dipilih dari look up dengan menekan tombol gambar teropong; (4) Isi jumlah pengeluaran; (5) Pilih kategori pengeluaran; (6) Isi kode tujuan, tekan "Enter" untuk menampilkan keterangan tujuan. Atau tekan gambar teropong untuk mencari data; (7) Tekan "Save" untuk menyimpan data.

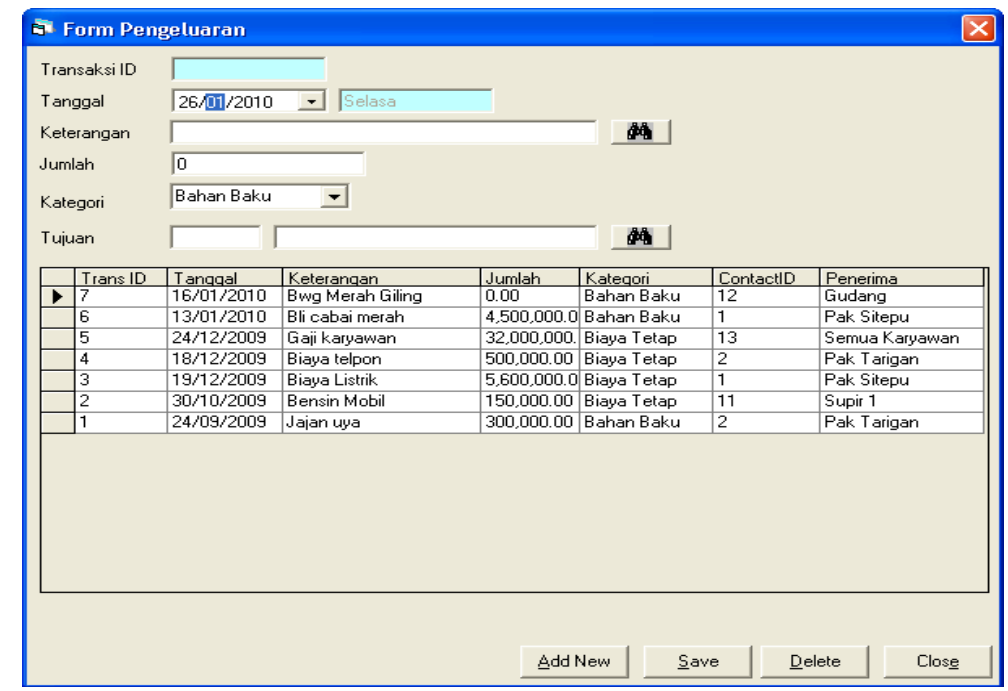

Gambar 10. Antarmuka untuk mencatat transaksi pengeluaran.

Untuk menampilkan laporan rugi laba (Gambar 11): (1) Pilih periode tanggal; (2) Klik "Generate" untuk menampilkan laporan.

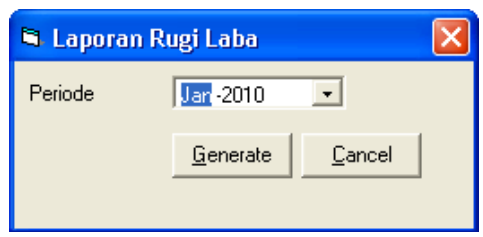

Gambar 11. Antarmuka untuk menampilkan laporan rugi laba. 
Untuk menampilkan laporan pengeluaran tidak tetap (Gambar 12): (1) Isi batasan tanggal dari tangal berapa sampai tanggal berapa; (2) Klik ”Generate” untuk menampilkan laporan.

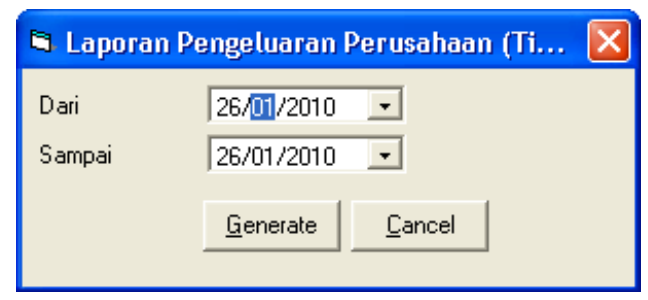

Gambar 12. Antarmuka untuk menampilkan laporan pengeluaran tidak tetap.

\section{PENUTUP}

Permasalahan yang dihadapi PD. Gerak Tani adalah semua kegiatan gudang belum dicatatkan. Dengan penggunaan sistem informasi yang dibuat permasalahan tersebut dapat diatasi. Demikian halnya dengan laporan keuangan perusahaan sudah dapat diketahui segera, baik pendapatan, pengeluaran, rugi laba dan sebagainya dapat diatasi sehingga dapat membantu manajemen perusahaan dalam mengambil keputusan.

Perancangan yang dilakukan hanya mencakup permasalahan yang dihadapi perusahaan saat ini sehingga sistem informasi ini masih perlu dikembangkan untuk menjadi sistem informasi yang sempurna bagi pengambilan keputusan perusahaan.

\section{DAFTAR PUSTAKA}

Lapin, L. L., Whisler, W.D. (2002). Quantitative Decision Making with Spreadsheet Applications. Belmont: Thompson Learning.

Mallach, E.G. (2000). Decision Support and Data Warehouse Systems. Singapore: Mc Graw Hill.

Marakas, G. M. (2003). Decision Support Systems. New Jersey: Prentice Hall.

Moore, J. H., Weatherford, L. R. (2001). Decision Modeling. New Jersey: Prentice Hall.

Suryadi, K., Ramdhani, A. (2000). Sistem Pendukung Keputusan. Bandung: Remaja Rosdakarya.

Turban, E., Aronson, J.E., Ting Peng Liang. (2007). Decision Support Systems and Intelligent Systems. New Jersey: Pearson Education. 